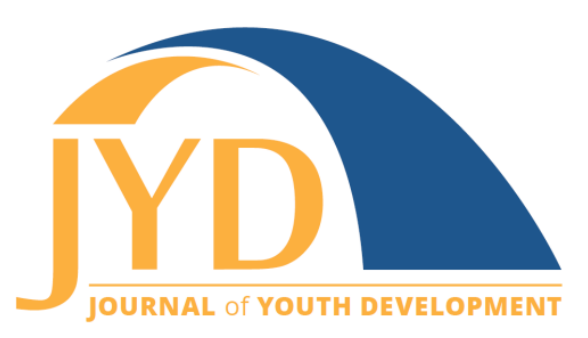

http://jyd. pitt. edu/ | Vol. 14 Issue 3 DOI 10.5195/jyd.2019.737 | ISSN 2325-4017 (online)

\title{
Bridging Families and Schools to Prevent Youth From Running Away From Home
}

\author{
Monica Bixby Radu \\ Southeast Missouri State University \\ mradu@semo.edu
}

\begin{abstract}
Running away from home is a serious problem among American youth. It has been linked to numerous negative social, psychological, and behavioral outcomes. It is well established that family dysfunction is one reason that youth run away from home. However, less research focuses on how both families and schools influence youths' likelihood of running away from home. Drawing from a sample of 4,546 youth from the 1997 National Longitudinal Survey of Youth, I examine how youths' perceptions of their schools' safety, experiences with bully victimization, and bonds with their families and their schools predict the likelihood of running away from home. I find that youths' negative perceptions of their schools'safety increase the likelihood that they will run away from home. Additionally, I discover that youth who have been the victims of bullying are more likely to run away from home compared to their peers who have not been bullied. My findings also suggest a cumulative effect between youths' perceptions of unsafe schools and experiences with bullying, suggesting that youth are most likely to run away from home when they feel unsafe at school and have been the victim of childhood bullying. These findings are important because they have implications for policy development. My findings suggest that (a) promoting a positive and inclusive school environment and (b) helping youth foster stronger relationships may help deter youth from running away from home.
\end{abstract}

Key words: running away from home, school safety, bullying, positive youth development, social capital

\section{Introduction}

In the United States, it is estimated that one in seven youths between the ages of 10 and 18years-old will run away from home, and youth ages 12 to 17 years old are at an increased risk of homelessness (National Conference of State Legislatures [NCSL], 2016). Runaways are youth under the age of 18 years who leave home for at least one night without their parents' or

(c) $\mathrm{EY}_{\mathrm{EY}}$ New articles in this journal are licensed under a Creative Commons Attribution 4.0 License. This journal is published by the University Library System, University of Pittsburgh and is cosponsored by the University of Pittsburgh Press. The Journal of Youth Development is the official peer-reviewed publication of the National Association of Extension 4-H Agents and the National AfterSchool Association. 
guardians' permission (Bailey, Camlin, \& Ennett, 1998; Hammer, Finkelhor, \& Sedlak, 2002). While most runaways do not experience long-term homelessness (Hammer et al., 2002; Milburn et al., 2007), running away from home places youth at an increased risk for numerous negative outcomes. For example, runaway youth are at an increased risk of physical (Whitbeck, Hoyt, \& Ackley, 1997; Whitbeck \& Simons, 1993) and sexual victimization (Kempf-Leonard \& Johansson, 2007). Recently, sexual victimization in the form of human or sex trafficking is a growing area of concern for runaway youth (Fedina, Perdue, Bright, \& Williamson, 2018; Middleton, Gattis, Frey, \& Roe-Sepowitz, 2018). Human traffickers often target youth runways and force or manipulate them into prostitution lasting days or even years (Polaris, 2019). Youth who run away from foster homes are especially vulnerable to becoming a human trafficking victims. This risk is further heightened for youth who are female, had prior experiences with psychological and sexual abuse, and had previous runaway episodes (Latzman, Gibbs, Feinberg, Kluckman, \& Aboul-Hosn, 2018). In addition to experiencing various forms of victimization, runaway youth often experience mental health (Tyler, Schmitz, \& Ray, 2018) and substance abuse issues (Martinez, 2006; McMorris, Tyler, Whitbeck, \& Hoyt, 2002; Simons \& Whitbeck, 1991; Whitbeck, 2017). Compared to their peers, runaways are more likely to be arrested and incarcerated (Biehal \& Wade, 1999). Hagan and McCarthy (1998) argue that this may be because running away from home introduces youth to new delinquent opportunities (e.g., prostitution, drug use, etc.), as well as the need to engage in them.

Family dysfunction, abuse, and neglect are reasons that youth often run away from home (Cauce et al., 2000; Gwadz, Nish, Leonard, \& Strauss, 2007; Jeanis, Fox, \& Muniz, 2018; Radu, 2017; Tyler, Cauce, \& Whitbeck, 2004; Tyler, Hagewen, \& Melander, 2011; Tyler, Hoyt, Whitbeck, \& Cauce, 2001; Whitbeck, 2017; Whitbeck, Hoyt, \& Yoder, 1999). Research is relatively conclusive that family dysfunction is associated with higher rates of running away from home. However, the primary focus on negative family environments neglects other important contexts in youths' lives, such as schools. Additionally, the focus on family dysfunction overlooks families' strengths and resiliency. This leaves several questions unanswered. How important are youths' perceptions of their schools' environments for deterring youth from running away from home? Do negative experiences at school or with youths' peers influence their decisions to leave home without their parents' permission? Do positive relationships between parents and their children help deter youth from running away from home?

To address these questions, I first examined whether youths' perceptions of their schools' safety influences the likelihood that youth will run away from home. Youth spend a large 
portion of their time at school. Consequently, running away from home may be a means to avoid attending a school they deem unsafe and circumvent harassment from their peers at school. Because research establishes that victimization is a driving force behind youths' decisions to run away from home, I also explored whether youths' experiences with bullying and other forms of victimization increased their likelihood of running away from home. Next, I took a unique approach by assessing family strengths. Instead of focusing on victimization within the context of the family, I assessed if a positive family environment may help prevent youth from running away from home. Additionally, I examined whether school resources in the form of school social capital affect youths' likelihood of becoming runaways. In addition, to better understand the combined effect of youths' perceptions and experiences, I examined how together, youths' perceptions of their schools' safety and experiences with bullying predict youths' likelihood of running away from home.

\section{Students' Perceptions of Schools' Safety and Bullying}

Running away from home is a serious problem and negative perceptions of youths' schools environments may be a contributing factor (Radu, 2017). Studies consistently find that a safe school environment may help reduce delinquency (Cernkovich \& Giordano, 1992; Liska \& Reed, 1985; O'Donnell, Hawkins, Catalano, Abbott, \& Day, 1995; Popp \& Peguero, 2012). However, it is unclear whether youths' perceptions of their schools' safety influences runaway behaviors. While we know that there is an association between running away from home and educational issues, such as dropping out of school and higher rates of suspension and expulsion (Hagan \& McCarthy, 1998; Whitbeck et al., 1999), few studies examine if youths' perceptions of their schools' safety influence their decisions to leave home.

Bullying is one form of peer victimization that is a serious problem for many youths. The Centers for Disease Control (2018) estimate that in 2017, $19 \%$ of youths were bullied at school and nearly $7 \%$ of youths reported not attending school due to safety concerns. Olweus (1991) describes bullying as the repeated physical and/or psychological aggression that is perpetrated with the intention to cause harm to one or more individuals. There are numerous negative consequences associated with bully victimization, including social strain with peers (Nansel, Craig, Overpeck, Saluja, \& Ruan, 2004), higher rates of avoidance behaviors (Hutzell \& Payne, 2012) and truancy (Lane, 1989), and an increased risk of engaging in subsequent violence (Radu, 2018). Yet, relatively unstudied is how bully victimization influences youths' likelihood of running away from home (Radu, 2017). My approach considers how students' perceptions of 
school safety and experiences with bullying victimization both individually and collectively influence youths' likelihood of running away from home.

\section{Other Factors Associated with Running Away From Home}

Several demographic factors are associated with running away from home. Females are more likely to run away from home than males (Morewitz, 2016; Sanchez, Waller, \& Greene, 2006) and African-American and Latino adolescents are less likely to run away from home than their White/non-Latino counterparts (Tyler \& Bersani, 2008). Youth ages 12 years and older are at an increased risk of running away from home (Benoit-Bryan, 2015). There is a strong relationship between family structure (Kim, Chenot, \& Lee, 2015; Sanchez et al., 2006) and behavioral problems (Substance Abuse and Mental Health Services Administration, 2004) predicting youths' likelihood of running away from home.

Holliday, Edelen, and Tucker (2017) point out that it is important to consider that runaways are a heterogeneous group, and youth tend to vary in terms of their individual characteristics and motivations for leaving home. While considering individual characteristics helps us better identify who runs away from home, understanding positive youth development theories helps explain both who and why youth may run away from home. Therefore, I draw from two interdisciplinary perspectives that provide frameworks for understanding positive youth development: ecological systems theory and social capital theory.

\section{Positive Youth Development}

\section{Ecological Systems Theory}

Bronfenbrenner's $(1974,1979)$ ecological systems theory emphasized the importance of considering resources from multiple contexts that may potentially influence youths' socialization and development. Two important contexts are families and schools. Bronfenbrenner conceptualized the ecological environment as a set of nested structures, including (a) the microsystem, (b) the mesosystem, and (c) the macrosystem. He argued that human development involves the way in which individuals perceive these social structures. The microsystem consists of patterns of activities, roles, and interpersonal relationships that individuals experience in a given setting. The mesosystem comprises the interrelations among two or more settings in which individuals actively participate, such as the relationships among home, school, and one's peer group. These connections employ additional forms, including 
social networks, communication among settings, and the extent and nature of knowledge and attitudes existing in one setting about the other. The macrosystem exists at the level of one's subculture and includes belief systems. Additionally, these systems extend beyond each context to encompass functional systems between settings. For example in this study, youth are embedded within the microsystem of their families, the mesosystem of relationships between microsystems (e.g., their families and schools), and the macrosystem of their cultural beliefs and perceptions of these systems (Bronfenbrenner, 1974, 1979).

The strength of using ecological systems theory as a framework for this study is that it considers how each context individually and collectively impacts youths' likelihood of running away from home. Few studies account for the influence of institutions external to the family when predicting youths' likelihood of running away from home. This is problematic because some studies find that families are more important than schools for promoting child social development (Parcel \& Dufur, 2001) and deterring delinquency (Dufur, Hoffmann, Braudt, Parcel, \& Spence, 2015). Other studies suggest that school resources may be especially beneficial when family resources are limited (Greenwald, Hedges, \& Laine, 1996). This suggests that the process of children's socialization is complex, involving multiple social systems, with two critical social systems being the family and the school. In the next section I discuss how families and schools have the potential to make capital investments in children and adolescents in the forms of family social capital and school social capital.

\section{Social Capital Theory: Family and School Social Capital}

Social capital refers to connections between and among individuals that produce social outcomes, reflecting the value of relationships between people (Coleman, 1990). Social capital theory poses that individuals benefit through their social relationships and participation in groups. Coleman $(1988,1990)$ argues that social capital is developed through family interaction, and parental interest in their children, parental monitoring, and extended family exchange and support are also forms of family social capital. Hagan and McCarthy's (1998) version of social capital theory suggests that youth are more likely to run away from disadvantaged homes because parents have less social capital. Lower levels of social capital may include weakened bonds between parents and their children and inconsistent and harsh parenting, both of which increase youths' likelihood of running away from home (Hagan \& McCarthy, 1998). This is supported by other studies, such as Bursik's (1999) research that suggests that social capital is an informal mechanism that may help control delinquent and criminal behaviors. Research consistently finds that adolescents with lower levels of family 
social capital are more likely to engage in problematic behaviors (Dufur et al., 2015; Dufur, Parcel, \& McCune, 2008; Dufur, Parcel, \& Troutman, 2013; Milkie, Nomaguchi, \& Denny, 2015), which may include running away from home (Luster \& Small, 1994).

Capital at school also affects children's academic, behavioral, and social outcomes (Parcel, Dufur, \& Cornell Zito, 2010). High levels of school social capital include positive perceptions of schools' teachers and fairness in terms of grading and discipline (Radu, 2018). Parcel and Bixby (2016) argue that school social capital also consists of bonds between parents and schools. Strong connections between parents and schools create bridging social capital between the family and the school (Coleman, 1991; Parcel \& Bixby, 2016; Parcel et al.; 2010; Putnam, 2000). Dika and Singh (2002) suggest that school-wide parental involvement in school activities, such as helping with fundraisers, taking an active role through parent-teacher conferences, and assisting in classroom duties, may contribute to the overall well-being and functioning of the school. Parochial schools may have a positive impact on student outcomes, possibly owing to student-teacher bonds, a form of social capital and values shared by family, community members, the church and school (Parcel \& Dufur, 2001). Additional studies, such as Maddox and Prinz (2003) argue that social bonds to schools may discourage students from engaging in behaviors that do not align with the values and norms of the school. Consequently, these studies suggest that social capital may take several forms and that each is important for reducing youths' likelihood of running away from home.

\section{Current Study}

While research shows that multiple contexts influence youths' socialization and development, research continues to overlook key aspects of these contexts, including youths' perceptions of their schools' safety and youths' experiences with victimization both at school and in other contexts. Therefore, my approach contributes to the literature by examining how running away from home is affected by multiple contexts. Additionally, victimization is one of the strongest predictors of running away from home and perceiving one's school as unsafe may exacerbate the effects of bully victimization on the likelihood of running away from home, which is why I examine the combined effect of negative perceptions of schools' safety and bully victimization predicting the likelihood of running away from home. 


\section{Data and Measures}

I used data from the National Longitudinal Survey of Youth 1997 (Bureau of Labor Statistics, U.S. Department of Labor, 2015; hereafter NLSY97). The NLSY97 is a household-based, nationally representative longitudinal study, following a cohort of youth born between the years 1980 through 1984 with Wave 1 starting in 1997, continuing to Wave 16 collected in 2013. The oldest respondents were 16 years old as of December 31,1996 and the youngest were 12 years old. The initial sample included 8,984 individuals originating from 6,819 unique households; 1,862 households included more than one NLSY97-eligible respondent. Of the 8,984 total respondents, 4,546 respondents were considered eligible for this study because they were (a) between the ages of 13 and 15 at Wave 2 of the survey and (b) living with a parent or guardian at the date of the interview. I focused my analysis on 13 to 15-year-olds because recently there has been a shift in younger youths leaving home prematurely (NCSL, 2016); therefore, more research is needed that focuses on the runaway behaviors of this younger cohort of youth. I measured my dependent variable, running away from home at Wave 2 (1998) from a question asking respondents if they had left home and stayed away at least one night without their parent's prior knowledge or permission since the date of the last interview at Wave 1 (1997) of the survey.

\section{Independent Variables}

\section{Perception of School Safety, Bullying, and Other Forms of Victimization}

I measured perception of school safety at Wave 1 (1997) with a survey question asking respondents, "Do you feel safe at school?" Responses ranged from 1 (strongly disagree) to 4 (strongly agree). I measured bullying with the question, "Before you turned age 12, were you ever the victim of repeated bullying?" and responses included 1 (yes) or 0 (no). I used two variables to measure school-based victimization: threatened at school and victim of property theft at school, which are included in analysis as dichotomous variables. As additional measures of victimization, respondents were asked if their house was ever broken into when they were a child and if they had ever witnessed a shooting as a child. Witnessing extreme violence, such as a shooting, is oftentimes referred to as "co-victimization" and is associated with serious consequences like those resulting from direct victimization (Shakoor \& Chalmers, 1991). This demonstrates the importance of including witnessing a shooting as a measure for victimization. I measured both forms of victimization as dichotomous variables: 1 (yes, experienced victimization) and 0 (no, did not experience victimization). 
Runaway Prevention: Bridging Families and Schools

\section{Family Social Capital, School Social Capital, and Other Family Characteristics}

To measure family social capital, I created an index that included three measures for parental involvement or time parents spend with their children and one measure for parental knowledge of child's teachers and school. The index ranged from 0 , indicating low levels of family social capital, to 25, suggesting high levels of family social capital. Factor analysis suggests that all four items load on one factor, with a Cronbach's alpha of .641 indicating a moderate level of reliability. To measure school social capital, I created an index from questions at Wave 1 (1997). Respondents were asked if (a) teachers are interested in students' success at school, (b) the grading system was utilized fairly at school, and (c) discipline was fair. Factor analysis suggests that all three items loaded on one factor, and the Cronbach's alpha of .734 indicates a moderate level of reliability. I used three additional measures of school social capital, the first being type of school, 1 (parochial school) and 0 (all other schools). Secondly, I measured if schools have school-wide parental involvement in school. My final measure of school social capital was student-teacher ratio; a lower student-teacher ratio provides an opportunity for stronger bonds between students and teachers (Parcel \& Dufur, 2001). I also included gross household income as a categorical variable with most household income reports $(97 \%)$ coming from the respondents' parents. In addition, I included measures for both residential paternal and residential maternal years of completed education to reflect family socioeconomic status. I controlled for prior runaway experiences, delinquency, peer delinquency, race/ethnicity, sex, family structure, and age.

\section{Analysis}

I tested for multicollinearity by examining bivariate correlations between each of the independent variables, and both the tolerance scores and variance inflation factor (VIF) scores indicate that multicollinearity does not challenge the findings. The average missing data across independent variables was approximately $10 \%$, which is not uncommon in longitudinal datasets (Enders, 2010). I used a series of five random imputations to estimate values for missing data across all independent variables. Using logistic regression, my analysis predicted the binary outcome variable, likelihood of running away from home in 1998 from sets of independent variables measured in 1997. In Model 1, I tested whether perception of schools' safety influenced youths' likelihood of running away from home. In Model 2, I added measures of victimization occurring at school and in other contexts. Model 3 tested the effect of perception of school safety and family social capital, while Model 4 introduced perception of school safety and school social capital to predict youths' likelihood of running away from home. In Model 5, I 
Runaway Prevention: Bridging Families and Schools

included all independent variables and control variables. In Model 6, I tested the interaction effect between bully victimization and perception of schools' safety predicting running away from home.

\section{Results}

Table 1 includes descriptive statistics for all variables included in analysis, and the bivariate correlations between each independent variable and the dependent variable, running away from home. At Wave 2 (1998) almost seven percent of respondents reported that they had run away from home since the date of the last interview. On average, most respondents "agreed" that they felt safe at school. Almost $20 \%$ of respondents specified that they had been victims of bullying. Table 1 also shows that perception of school safety is negatively correlated with running away from home ( $p \leq .001$, two-tailed).

Table 2 presents results from logistic regression models predicting likelihood of running away from home in 1998. Model 1 shows support for my hypothesis that perceiving one's school as safe is negatively associated with running away from home $(-.474, p \leq .001$, two-tailed). In Model 2, I find partial support for my hypothesis that experiences with victimization are statistically significant positive predictors of running away from home. Respondents who had been the victim of bullying $(.423, p \leq .01)$ and threatened at school $(.085, p \leq .05)$ are more likely to run away from home compared to their peers who did not experience these forms of victimization. Witnessing a shooting $(.531, p \leq .001)$ also increases the likelihood that youths will run away from home. Model 3 demonstrates support for my hypothesis that family social capital is negatively correlated with and a statistically significant predictor of youths' likelihood of running away from home $(-.066, \mathrm{p} \leq .001)$. 
Table 1. Descriptive Statistics and Bivariate Correlations with Running Away From Home, $N=4,546$

\begin{tabular}{|c|c|c|c|}
\hline & Mean & Min-Max & $\begin{array}{l}\text { Bivariate } \\
\text { correlation }\end{array}$ \\
\hline \multicolumn{4}{|l|}{ Dependent variable (1998) } \\
\hline Ran away from home (in the past year) & .067 & $0-1$ & \\
\hline \multicolumn{4}{|l|}{ Independent variables (1997) } \\
\hline Perception of school safety & 3.18 & $1-4$ & $-.093 * * *$ \\
\hline Victim of bullying & .195 & $0-1$ & $.082 * * *$ \\
\hline Victim of threats at school & .555 & $0-1$ & $.085^{* * *}$ \\
\hline Victim of property theft at school & .419 & $0-1$ & $.044 * * *$ \\
\hline Victim of home burglary & .154 & $0-1$ & $.048 * * *$ \\
\hline Witnessed shooting & .105 & $0-1$ & $.075^{* * *}$ \\
\hline Family social capital & 12.27 & $0-25$ & $-.088^{* * *}$ \\
\hline Gross household income & 2.95 & $1-5$ & $-.065 * * *$ \\
\hline Father's education (in years) & 12.30 & $2-20$ & $-.060 * *$ \\
\hline Mother's education (in years) & 12.55 & $2-20$ & -.012 \\
\hline School social capital & 9.16 & $3-12$ & $-.112 * * *$ \\
\hline Parochial school & .065 & $0-1$ & $-.031 *$ \\
\hline School-wide parental involvement & .374 & $0-1$ & -.021 \\
\hline Student-teacher ratio & 2.34 & $1-4$ & .015 \\
\hline Prior runaway episode & .064 & $0-1$ & $.181^{* * *}$ \\
\hline Delinquency index & 1.39 & $0-7$ & $.203 * * *$ \\
\hline Peer delinquency index & 1.07 & $0-5$ & $.080 * * *$ \\
\hline Black/African American & .242 & $0-1$ & -.010 \\
\hline Hispanic/Latino & .214 & $0-1$ & .014 \\
\hline Other race/ethnicity & .009 & $0-1$ & .022 \\
\hline Males & .517 & $0-1$ & $-.039 * *$ \\
\hline Two biological parent family & .728 & $0-1$ & $-.015^{* *}$ \\
\hline Age (year of birth) & 1983 & $1982-1984$ & $-.045^{* *}$ \\
\hline
\end{tabular}

Note. All tests were 2-tailed; $* * * p \leq .001, * * p \leq .01, * p \leq .05$

Model 3 shows that perception of school safety remains statistically significant and negative in predicting youths' likelihood of running away from home, net of family social capital, gross 
Runaway Prevention: Bridging Families and Schools

household income, and both father's and mother's level of completed education. Model 4 indicates that school social capital is statistically significant and negative in predicting running away from home $(-.197, p \leq .001)$, which supports my hypothesis that high levels of school social capital prevent youth from running away from home. Attending parochial school, schoolwide parental involvement, and student-teacher ratio are not statistically significant in predicting youths' likelihood of running away from home.

Model 5 includes all independent variables and the control variables. Model 5 demonstrates that perception of school safety remains statistically significant and negative $(-.210 ; p \leq .05)$ in predicting the likelihood of running away from home, net of the control variables. Model 5 also shows that both family social capital and school social capital remain statistically significant and negative predicting youths' likelihood of running away from home even after controlling for a prior runaway episode $(.923, p \leq .001)$, delinquency $(.285, p \leq .001)$, and the remaining control variables. Following prior research, Model 5 also shows that females are more likely to run away from home compared to males $(-.556, p \leq .001)$.

In Model 6, I test my hypothesis that perception of school safety moderates the relationship between bully victimization and youths' likelihood of running away from home. I find support for this hypothesis. Figure 1 illustrates Model 6 graphically, showing the nature of the interaction effect between bully victimization and perception of school safety predicting youths' likelihood of running away from home. As shown in Figure 1, youth who were the victims of childhood bullying who reported that they "strongly disagreed" that they felt safe at school were the most likely to run away from home. While we know that both bully victimization and feeling unsafe at school are linked to negative adolescent outcomes, Figure 1 illustrates that together, youths are at cumulative disadvantage in terms of their likelihood of running away from home when they report both being the victim of childhood bullying and feeling unsafe at school. Yet, for youths who were the victim of childhood bullying, a positive perception of their schools' safety considerably decreased their likelihood of running away from home. 
Journal of Youth Development | http://jyd.pitt.edu/ | Vol. 14 Issue 3 DOI 10.5195/jyd.2019.737 Runaway Prevention: Bridging Families and Schools

Table 2. Summary of Logistic Regression Analyses Predicting Likelihood of Running Away From Home $(N=4546)$

\begin{tabular}{|c|c|c|c|c|c|c|}
\hline & Model 1 & Model 2 & Model 3 & Model 4 & Model 5 & Model 6 \\
\hline $\begin{array}{l}\text { Perception of school } \\
\text { safety }\end{array}$ & $\begin{array}{l}-.474 * * * \\
(.622)\end{array}$ & $\begin{array}{l}-.325 * * * \\
(.722)\end{array}$ & $\begin{array}{l}-.400 * * * \\
(.671)\end{array}$ & $\begin{array}{l}-.281 * * * \\
(.821)\end{array}$ & $\begin{array}{l}-.210^{*} \\
(.811)\end{array}$ & $\begin{array}{l}-.319 * * * \\
(.727)\end{array}$ \\
\hline Victim of bullying & & $\begin{array}{l}.423 * * \\
(1.53)\end{array}$ & & & $\begin{array}{l}.242+ \\
(1.27)\end{array}$ & $\begin{array}{l}-.784 \\
(.457)\end{array}$ \\
\hline $\begin{array}{l}\text { Victim of threats at } \\
\text { school }\end{array}$ & & $\begin{array}{l}.085^{*} \\
(1.09)\end{array}$ & & & $\begin{array}{l}.049 \\
(1.05)\end{array}$ & $\begin{array}{l}.054 \\
(1.06)\end{array}$ \\
\hline $\begin{array}{l}\text { Victim of property theft } \\
\text { at school }\end{array}$ & & $\begin{array}{l}.017 \\
(1.02)\end{array}$ & & & $\begin{array}{l}-.018 \\
(.982)\end{array}$ & $\begin{array}{l}-.018 \\
(.982)\end{array}$ \\
\hline Victim of home burglary & & $\begin{array}{l}.267+ \\
(1.31)\end{array}$ & & & $\begin{array}{l}.144 \\
(1.16)\end{array}$ & $\begin{array}{l}.154 \\
(1.17)\end{array}$ \\
\hline Witnessed shooting & & $\begin{array}{l}.531^{* * *} \\
(1.71)\end{array}$ & & & $\begin{array}{l}.166 \\
(1.18)\end{array}$ & $\begin{array}{l}.169 \\
(1.18)\end{array}$ \\
\hline Family social capital & & & $\begin{array}{l}-.066 * * * \\
(.936)\end{array}$ & & $\begin{array}{l}-.027 * \\
(.976)\end{array}$ & $\begin{array}{l}-.026 * \\
(.974)\end{array}$ \\
\hline $\begin{array}{l}\text { Gross household } \\
\text { income }\end{array}$ & & & $\begin{array}{l}-.110 * \\
(.896)\end{array}$ & & $\begin{array}{l}-.102 \dagger \\
(.903)\end{array}$ & $\begin{array}{l}-.103 \dagger \\
(.902)\end{array}$ \\
\hline $\begin{array}{l}\text { Father's education } \\
\text { (in years) }\end{array}$ & & & $\begin{array}{l}-.016 \\
(.985)\end{array}$ & & $\begin{array}{l}-.014 \\
(.986)\end{array}$ & $\begin{array}{l}-.014 \\
(.986)\end{array}$ \\
\hline $\begin{array}{l}\text { Mother's education } \\
\text { (in years) }\end{array}$ & & & $\begin{array}{l}.007 \\
(1.01)\end{array}$ & & $\begin{array}{l}-.001 \\
(.999)\end{array}$ & $\begin{array}{l}.000 \\
(1.00)\end{array}$ \\
\hline School social capital & & & & $\begin{array}{l}-.197 * * * \\
(.821)\end{array}$ & $\begin{array}{l}-.088^{*} \\
(.916)\end{array}$ & $\begin{array}{l}-.088^{*} \\
(.916)\end{array}$ \\
\hline Parochial School & & & & $\begin{array}{l}-.398 \\
(.672)\end{array}$ & $\begin{array}{l}-.190 \\
(.827)\end{array}$ & $\begin{array}{l}-.183 \\
(.833)\end{array}$ \\
\hline $\begin{array}{l}\text { School-wide parental } \\
\text { involvement }\end{array}$ & & & & $\begin{array}{l}-.145 \\
(.865)\end{array}$ & $\begin{array}{l}-.141 \\
(.868)\end{array}$ & $\begin{array}{l}-.136 \\
(.873)\end{array}$ \\
\hline Student-teacher ratio & & & & $\begin{array}{l}.044 \\
(1.05)\end{array}$ & $\begin{array}{l}.046 \\
(1.05)\end{array}$ & $\begin{array}{l}.042 \\
(1.04)\end{array}$ \\
\hline
\end{tabular}


Journal of Youth Development | http://jyd.pitt.edu/ | Vol. 14 Issue 3 DOI 10.5195/jyd.2019.737 Runaway Prevention: Bridging Families and Schools

Table 2 (continued)

\begin{tabular}{|c|c|c|c|c|c|c|}
\hline & Model 1 & Model 2 & Model 3 & Model 4 & Model 5 & Model 6 \\
\hline Control Variables & & & & & & \\
\hline Prior runaway episode & & & & & $\begin{array}{l}.923 * * * \\
(2.52)\end{array}$ & $\begin{array}{l}.934 * * * \\
(2.55)\end{array}$ \\
\hline Delinquency index & & & & & $\begin{array}{l}.285^{* * *} \\
(1.33)\end{array}$ & $\begin{array}{l}.279 * * * \\
(1.32)\end{array}$ \\
\hline Peer delinquency index & & & & & $\begin{array}{l}-.045 \\
(.956)\end{array}$ & $\begin{array}{l}-.040 \\
(.961)\end{array}$ \\
\hline Black/African American & & & & & $\begin{array}{l}-.231 \\
(.794)\end{array}$ & $\begin{array}{l}-.250 \\
(.779)\end{array}$ \\
\hline Hispanic/Latino & & & & & $\begin{array}{l}.018 \\
(1.02)\end{array}$ & $\begin{array}{l}.019 \\
(1.02)\end{array}$ \\
\hline Other race/ethnicity & & & & & $\begin{array}{l}.406 \\
(1.50)\end{array}$ & $\begin{array}{l}.435 \\
(1.55)\end{array}$ \\
\hline Males & & & & & $\begin{array}{l}-.556 * * * \\
(.573)\end{array}$ & $\begin{array}{l}-.556 * * * \\
(.573)\end{array}$ \\
\hline $\begin{array}{l}\text { Two-biological parent } \\
\text { family }\end{array}$ & & & & & $\begin{array}{l}-.300 * \\
(.741)\end{array}$ & $\begin{array}{l}-.293 * \\
(.746)\end{array}$ \\
\hline Age (year of birth) & & & & & $\begin{array}{l}-.036 \\
(.965)\end{array}$ & $\begin{array}{l}-.035 \\
(.965)\end{array}$ \\
\hline $\begin{array}{l}\text { Perception of school } \\
\text { safety* }\end{array}$ & & & & & & $\begin{array}{l}.354 * \\
(1.43)\end{array}$ \\
\hline Constant & -1.17 & -1.93 & -.235 & -.052 & 70.89 & 69.52 \\
\hline -2 log likelihood & 2205.28 & 2166.03 & 2169.01 & 2175.56 & 1977.00 & 1972.98 \\
\hline Chi-square & 37.08 & 76.33 & 73.35 & 66.80 & 265.35 & 269.38 \\
\hline$d f$ & 1 & 6 & 5 & 5 & 23 & 24 \\
\hline
\end{tabular}

Note. All tests were 2-tailed; $* * * p \leq .001, * * p \leq .01, * p \leq .05, \dagger p \leq .10$. Values in parentheses are exponentiated $\beta$ (effects on the odds). 
Figure 1. Predicted Probability of Running Away From Home by Perception of School Safety and Bully Victimization

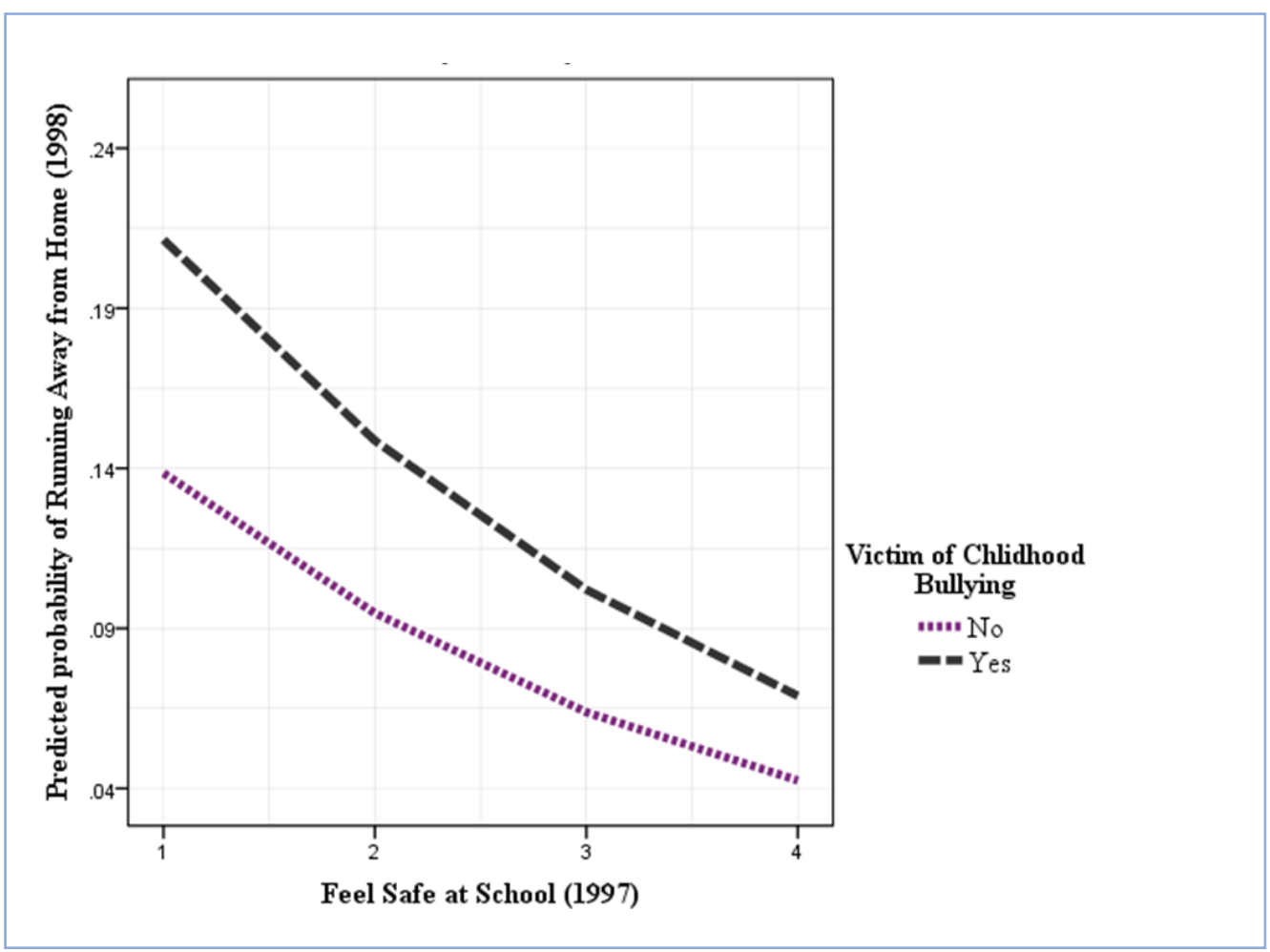

\section{Additional Analysis}

High levels of family social capital and school social capital each have the potential to prevent youth from running away from home. However, these resources may be less effective in deterring youth from running away from home when youth have negative perceptions of their schools' safety. The relationship between family social capital and school social capital predicting running away from home may be moderated by youths' perceptions of their schools' safety. For example, I would expect that youth with the highest levels of family and school social capital who report feeling safe at school would be the least likely to run away from home. I examine these relationships by testing the interaction effects between (a) family social capital and perception of school safety and (b) school social capital and perception of school safety predicting youths' likelihood of running away from home. I individually add each interaction effect to the main effects model (Model 6) to predict youths' likelihood of running away from home. The interactive effects were not statistically significant $(p \leq .10)$, and therefore, were not shown in Table 2. This suggests that the magnitude or direction of the effect of family social capital and school social capital predicting the likelihood of running away from home was not 
Runaway Prevention: Bridging Families and Schools

conditional upon youths' perceptions of schools' safety. Further analysis considered if collectively, family social capital and school social capital deter youth from running away from home. The interaction effect between family social capital and school social capital was not statistically significant in predicting runaway behaviors.

\section{Discussion}

Existing research on the effects of family and school characteristics on adolescent outcomes rarely considers youths' perceptions of their schools' safety when studying problem behaviors during adolescence. Prior research on runaways focuses primarily on youths' unstable home environments and experiences with family neglect and abuse. I took a different approach, as my primary objective was to test whether youths' perceptions of their schools as unsafe increased their likelihood of running away from home. I find support for this idea. Perception of school safety proves to be an important deterrent for running away from home in all five additive models. In the final additive model (Model 5), youths' perceptions of their schools' safety continue to be an important predictor of running away from home, even when controlling for experiences with victimization, family social capital, household income, socioeconomic status, and other key factors known to affect youths' likelihood of running away from home. This suggests that even with high levels of family resources, when youth feel unsafe at school they are more likely to run away from home compared to youth who have positive perceptions of their schools' environments.

I also evaluated the effects of several forms of victimization on running away from home. I find support for my hypothesis that experiences with bullying and other forms of victimization both internal and external to the school increase youths' likelihood of running away from home. While research establishes that there are numerous negative consequences associated with being the victim of bullying, my findings suggest that experiences with bullying have long-term effects of youths' behavioral outcomes, such as running away from home. This suggests that in addition to the academic and social consequences associated with bullying, bully victims may attempt to escape being the victim of subsequent bullying by leaving home. Unfortunately, running away from home typically places youth at a greater risk for numerous other forms of victimization, which makes running away from home a dangerous and ineffective mechanism for coping with bullying. Additionally, the relationship between being the victim of childhood bullying and youths' perceptions of their schools' safety suggests that negative perceptions and negative experiences have cumulative effects on running away from home. That is, youth are 
most likely to run away from home if they have been the victim of bullying and perceive their school as unsafe.

My analysis also suggests that both family resources and school resources in the form of social capital are important for preventing youth from running away from home. I found that higher levels of both family social capital and school social capital may discourage youth from becoming runaways. While previous research supports the notion that dysfunctional families predict running away from home, my findings suggest that the time youths spend with their families and the positive connections youths have with their schools are important resources for discouraging running away from home. This could help guide future policy that is interested in ways in which multiple contexts could help promote positive youth and young adult outcomes.

\section{Limitations}

Variations in students' perceptions of their schools' safety and experiences with victimization may be linked to attending poor-quality schools or living in disadvantaged neighborhoods. Racial/ethnic minority youth and youth from lower socioeconomic families are more likely to attend these poorer quality schools and reside in less advantaged neighborhoods. My study does not address the complexities of racial/ethnic inequalities or economic disparities linked to disadvantaged schools/neighborhoods. In addition, while LGBT youth tend to experience disproportionately high rates of homelessness each year (Keuroghlian, Shtasel, \& Bassuk, 2014), data limitations prevented me from testing the relationship between youths' sexual orientation and/or gender identity and running away from home. It is important to note that while youth in foster care have higher rates of running away from home than youth living at home (King, Abrego, Narendorf, Ha, \& Santa Maria, 2017), the current research focuses primarily on youth who were residing at home at the time of their runaway episode.

While my analysis focused on family strengths in the form of family social capital, it is important to note that family victimization is associated with higher rates of running away from home (Whitbeck, 2017). Data limitations prevented me from incorporating additional measures of family victimization. Additional data sets were considered for this analysis, including the Education Longitudinal Study of 2002 (ELS: 2000). However, I determined that several indicators were either not included in the survey or the NLSY97 had superior measures. For example, the ELS: 2000 lacks questions about delinquency and peer group delinquency both of which are associated with higher rates of running away from home. Also, the ELS: 2000 asks youth how many times they experienced bullying during the first semester/term of the same 
school year, rather than asking respondents if they had ever experienced bullying. The NLSY97 captures respondents' experiences with bullying and other forms of victimization during childhood and early adolescence.

This analysis was based on the experiences of a cohort of youth prior to the existence of bullying through text messaging, social media, and other forms of technology. Recently, there is growing concern about cyberbullying (Aivazpour \& Beebe, 2018; Zych, Baldry, Farrington, \& Llorent, 2018). Similar to traditional bullying, cyberbullying is associated with severe consequences (Abreu \& Kenny, 2018; Balakrishnam, 2018). I argue that running away from home may be an additional negative outcome. For youth, escaping cyberbullying may be difficult because the mobility of technology allows youth to be bullied concurrently in several different contexts with a wider audience (Motswi \& Mashegoane, 2017). Because of these issues, I expect that cyberbullying may have more of an effect on youths' likelihood of running away from home compared to traditional forms of bullying. Future research should consider replicating this analysis with more recent data to examine how cyberbullying may influence youths' likelihood of running away from home. Additional research should also take into account that youth may be victims of both traditional and cyberbullying. Together, these forms of harassment may have compound effects on youths' well-being and increase their likelihood of running away from home.

\section{Conclusion}

Better understanding of how multiple contexts and risk factors influence youths' likelihood of running away from home may help in preventing future run away episodes and improve treatment outcomes for those who have run away from home and experienced negative events while away from home (Hershberger et al., 2018). Besides time spent at home, youth spend most of their time at school (Larson, 2001). If remaining at home means attending a school that youth deem negative in terms of safety, youth may choose to leave home rather than be required to attend school. Strict truancy laws require parents to send their children to school, particularly if they are under 16 years old (Gleich-Bope, 2014). This suggests that neither the youth nor their parents may feel that they have much control over whether or not a minor attends school on a regular basis. While some families may have the knowledge and resources to choose their children's schools, for many, changing schools is not an option (Parcel \& Taylor, 2015). Therefore, it is important to consider ways to improve youths' perceptions of their schools' environments and stop bullying. 
Runaway Prevention: Bridging Families and Schools

Promoting a more positive and inclusive peer culture may discourage bullying, which in turn may help prevent youth from running away from home (Lyng, 2018). Studies suggest that implementing interventions that focus on both individual and contextual factors may keep youth from bullying their peers (Espelage, Van Ryzin, \& Holt, 2018). One approach to help foster more positive and inclusive peer culture is youths' engagement in structured after-school programs that focus on youth development (e.g., 4-H, Boy Scouts and Girl Scouts, YMCA, Boys and Girls Club, etc.) and time spent involved in civic engagement ( $\mathrm{Li}$, Bebiroglu, Phelps, Lerner, \& Lerner, 2008). Li and colleagues found that youths' increased time spent engaged in meaningful out-ofschool activities deterred them from engaging in adverse activities. Additionally, social media may also be used as a mechanism to help provide support for youth, as Lee and Horsely (2017) found that the use of a 4-H Facebook page helped encourage positive youth development through civic engagement.

When youth feel socially connected to organizations outside of the school-if issues arise at home or at school-their social bonds to these groups may help prevent youth from running away from home. Additionally, organizations that include structured, parental-supervised activities may provide youth with other forms of adult support beyond their teachers and parents. Consequently, positive adult relationships are important for youth because they provide another outlet to report problematic issues at home or at school. Recently, the "Pathways to Success" Program emphasized the role of positive adult relationships in youths' lives (Davis, Prendergast, \& McHugh, 2018). Youths' interaction with mentors, coaches, advisors and other positive adults help youth build community connections. In turn, these connections help prevent problematic behaviors and outcomes, including youth homelessness (Davis et al., 2018).

Helping youth develop more supportive relationships with their schools and with their peers is important for preventing runaway episodes. Improving youths' perceptions of their schools' environments and cultivating more positive experiences among youth may act as protector buffers to assist and comfort youth if they are feeling isolated from traumatic events going on at home. In turn, these positive experiences and relationships may help mediate the relationship between dysfunctional family environments and runaway episodes. Future research should consider examining these complex relationships to help develop policies that address how resources from multiple contexts and positive social relationships may influence youths' decisions to run away from home. 


\section{References}

Abreu, R. L., \& Kenny, M. C. (2018). Cyberbullying and LGBTQ youth: A systematic literature review and recommendations for prevention and intervention. Journal of Child \& Adolescent Trauma, 11(1), 81-97. doi:10.1007/s40653-017-0175-7

Aivazpour, Z., \& Beebe, N. (2018). Cyberbullying: Investigating the roles of power and communication medium. Association for Information Systems. Retrieved from https://aisel.aisnet.org/amcis2018/Security/Presentations/35/.

Bailey, S., Camlin, C., \& Ennett, S. (1998). Substance use and risky sexual behavior among homeless and runaway youth. Journal of Adolescent Health, 23(6), 378-388.

Balakrishnan, V. (2018). Actions, emotional reactions and cyberbullying-From the lens of bullies, victims, bully-victims and bystanders among Malaysian young adults. Telematics and Informatics, 35(5), 1190-1200. doi:10.1016/j.tele.2018.02.002

Benoit-Bryan, J. (2015). National Runaway Safeline's 2015 reporter's source book on runaway and homeless youth. Chicago, IL: National Runaway Safeline.

Biehal, N., \& Wade, J. (1999). Taking a chance? The risks associated with going missing from substitute care. Child Abuse Review, 8(6), 366-376. doi:10.1002/(SICI)10990852(199911/12)8:6<366::AID-CAR582>3.0.CO;2-G

Bronfenbrenner, U. (1974). Developmental research, public policy, and the ecology of childhood. Child Development, 45(1), 1-5. doi:10.2307/1127743

Bronfenbrenner, U. (1979). The ecology of human development. Cambridge, MA: Harvard university press.

Bureau of Labor Statistics, U.S. Department of Labor. (2015). National longitudinal survey of youth 1997 cohort, 1997-2013 (rounds 1-16). Chicago, IL: National Opinion Research Center, The University of Chicago, and Columbus: Center for Human Resource Research, The Ohio State University.

Bursik Jr, R. J. (1999). The informal control of crime through neighborhood networks. Sociological Focus, 32(1), 85-97. doi:10.1080/00380237.1999.10571125

Cauce, A. M., Paradise, M., Ginzler, J. A., Embry, L., Morgan, C. J., Lohr, Y., \& Theofelis, J. (2000). The characteristics and mental health of homeless adolescents: Age and gender differences. Journal of Emotional and Behavioral Disorders, 8(4), 230-239. doi:10.1177/106342660000800403

Centers for Disease Control \& Prevention, National Center for HIV/AIDS, Viral Hepatitis, STD, and TB Prevention, Division of Adolescent and School Health. (2018). Youth Risk Behavior Surveillance System (YRBSS). Retrieved from https://www.cdc.gov/healthyyouth/data/yrbs/pdf/trendsreport.pdf

Cernkovich, S. A., \& Giordano, P. C. (1992). School bonding, race, and delinquency. Criminology, 30(2), 261-291. doi:10.1111/j.1745-9125.1992.tb01105.x 
Journal of Youth Development | http://jyd.pitt.edu/ | Vol. 14 Issue 3 DOI 10.5195/jyd.2019.737

Runaway Prevention: Bridging Families and Schools

Coleman, J. S. (1988). Social capital in the creation of human capital. American Journal of Sociology, 94, S95-S120.

Coleman, J. S. (1990). Foundations of Social Theory. Cambridge, MA: Belknap Press of Harvard University Press.

Coleman, J. S. (1991). Parental involvement in education. Policy Perspective: Office of Educational Research and Improvement. Washington, DC: U.S. Department of Education.

Davis, L., Prendergast, T., \& McHugh, D. (2018). Developing a model intervention to prevent homelessness among transition-age youth: The "Pathways to Success" program. Center for Policy Research: Denver, CO.

Dika, S. L., \& Singh, K. (2002). Applications of social capital in educational literature: A critical synthesis. Review of Educational Research, 72(1), 31-60. doi:10.3102/00346543072001031

Dufur, M. J., Hoffmann, J. P., Braudt, D. B., Parcel, T. L., \& Spence, K. R. (2015). Examining the effects of family and school social capital on delinquent behavior. Deviant Behavior, 36(7), 511-526. doi:10.1080/01639625.2014.944069

Dufur, M. J., Parcel, T. L., \& McKune, B. A. (2008). Capital and context: Using social capital at home and at school to predict child social adjustment. Journal of Health and Social Behavior, 49(2), 146161. doi:10.1177/002214650804900203

Dufur, M. J., Parcel, T. L., \& Troutman, K. P. (2013). Does capital at home matter more than capital at school? Social capital effects on academic achievement. Research in Social Stratification and Mobility, 31, 1-21. doi:10.1016/j.rssm.2012.08.002

Enders, C. K. (2010). Applied missing data analysis. New York, NY: The Guilford Press.

Espelage, D. L., Van Ryzin, M. J., \& Holt, M. K. (2018). Trajectories of bully perpetration across early adolescence: Static risk factors, dynamic covariates, and longitudinal outcomes. Psychology of Violence, 8(2), 141-150. doi:10.1037/vio0000095

Fedina, L., Perdue, T., Bright, C. L., \& Williamson, C. (2018). An ecological analysis of risk factors for runaway behavior among individuals exposed to commercial sexual exploitation. Journal of Child \& Adolescent Trauma, 1-11. doi:10.1007/s40653-018-0229-5

Gleich-Bope, D. (2014). Truancy laws: How are they affecting our legal systems, our schools, and the students involved? The Clearing House: A Journal of Educational Strategies, Issues and Ideas, 8オ(3), 110-114.

Greenwald, R., Hedges, L. V., \& Laine, R. D. (1996). The effect of school resources on student achievement. Review of Educational Research, 66(3), 361-396. doi:10.2307/1170528

Gwadz, M. V., Nish, D., Leonard, N. R., \& Strauss, S. M. (2007). Gender differences in traumatic events and rates of post-traumatic stress disorder among homeless youth. Journal of Adolescence, 30(1), 117-129. 
Hagan, J., \& McCarthy, B. (1998). Mean streets: Youth crime and homelessness. Cambridge, UK: Cambridge University Press.

Hammer, H., Finkelhor, D., \& Sedlack, A. J. (2002). Runaway/thrownaway children: National estimates and characteristics. (Juvenile Justice Bulletin - NCJ196469). Washington, DC: U.S. Government Printing Office.

Hershberger, A. R., Sanders, J., Chick, C., Jessup, M., Hanlin, H., \& Cyders, M. A. (2018). Predicting running away in girls who are victims of commercial sexual exploitation. Child Abuse \& Neglect, 79, 269-278. doi:10.1016/j.chiabu.2018.02.023

Holliday, S. B., Edelen, M. O., \& Tucker, J. S. (2017). Family functioning and predictors of runaway behavior among at-risk youth. Child and Adolescent Social Work Journal, 34(3), 247-258. doi:doi.org/10.1007/s10560-016-0459-z

Hutzell, K. L., \& Payne, A. A. (2012). The impact of bullying victimization on school avoidance. Youth Violence and Juvenile Justice, 104), 370-385. doi:10.1177/1541204012438926

Jeanis, M. N., Fox, B. H., \& Muniz, C. N. (2018). Revitalizing Profiles of Runaways: A Latent Class Analysis of Delinquent Runaway Youth. Child and Adolescent Social Work Journal, 1-17. doi:10.1007/s10560-018-0561-5

Kempf-Leonard, K., \& Johansson, P. (2007). Gender and runaways: Risk factors, delinquency, and juvenile justice experiences. Youth Violence and Juvenile Justice, 5(3), 308-327. doi:10.1177/1541204007301293

Keuroghlian, A. S., Shtasel, D., \& Bassuk, E. L. (2014). Out on the street: a public health and policy agenda for lesbian, gay, bisexual, and transgender youth who are homeless. American Journal of Orthopsychiatry, 84(1), 66-72.

Kim, H., Chenot, D., \& Lee, S. (2015). Running away from out-of-home care: A multilevel analysis. Children \& Society, 29(2), 109-121. doi:10.1111/chso.12019

King, B., Abrego, D., Narendorf, S., Ha, Y., \& Santa Maria, D. (2017). Representations of homelessness, home environments, and authority in the context of runaway behaviors reported by foster care youth residing in an emergency shelter. Journal of Social Distress and the Homeless, 26(2), 138147. doi:10.1080/10530789.2017.1350333

Lane, D. A. (1989). Bullying in school: The need for an integrated approach. School Psychology International, 10(3), 211-215. doi:10.1177/0143034389103007

Larson, R. W. (2001). How US children and adolescents spend time: What it does (and doesn't) tell us about their development. Current Directions in Psychological Science, 10(5), 160-164. doi:10.1111/1467-8721.00139

Latzman, N. E., Gibbs, D. A., Feinberg, R., Kluckman, M. N., \& Aboul-Hosn, S. (2018). Human trafficking victimization among youth who run away from foster care. Children and Youth Services Review, 98, 112-124. doi:10.1016/j.childyouth.2018.12.022 
Runaway Prevention: Bridging Families and Schools

Lee, A. R., \& Horsley, J. S. (2017). The role of social media on positive youth development: An analysis of 4-H Facebook page and 4-H'ers' positive development. Children and Youth Services Review, 77, 127-138. doi:10.1016/j.childyouth.2017.04.014

Li, Y., Bebiroglu, N., Phelps, E., Lerner, R. M., \& Lerner, J. V. (2008). Out-of-school time activity participation, school engagement and positive youth development: Findings from the 4-H study of positive youth development. Journal of Youth Development, 3(3), 22. doi: $10.5195 / j y d .2008 .284$

Liska, A. E., \& Reed, M. D. (1985). Ties to conventional institutions and delinquency: Estimating reciprocal effects. American Sociological Review, 50(4), 547-560. doi:10.2307/2095438

Luster, T., \& Small, S. A. (1994). Factors associated with sexual risk-taking behaviors among adolescents. Journal of Marriage and the Family, 56(3), 622-632.

Lyng, S. T. (2018). The Social Production of Bullying: Expanding the Repertoire of Approaches to Group Dynamics. Children \& Society. (available online ahead of print). DOI: 10.1111/chso.12281.

Maddox, S. J., \& Prinz, R. J. (2003). School bonding in children and adolescents: Conceptualization, assessment, and associated variables. Clinical Child and Family Psychology Review, 6(1), 31-49. doi:10.1023/A:1022214022478

Martinez, R. J. (2006). Understanding runaway teens. Journal of Child and Adolescent Psychiatric Nursing, 19(2), 77-88. doi:10.1111/j.1744-6171.2006.00049.x

McMorris, B. J., Tyler, K. A., Whitbeck, L. B., \& Hoyt, D. R. (2002). Familial and "on-the-street" risk factors associated with alcohol use among homeless and runaway adolescents. Journal of Studies on Alcohol, 63(1), 34-43.

Middleton, J. S., Gattis, M. N., Frey, L. M., \& Roe-Sepowitz, D. (2018). Youth experiences survey (YES): Exploring the scope and complexity of sex trafficking in a sample of youth experiencing homelessness. Journal of Social Service Research, 44(2), 141-157. doi:10.1080/01488376.2018.1428924

Milburn, N. G., Rosenthal, D., Rotheram-Borus, M. J., Mallett, S., Batterham, P., Rice, E., \& Solorio, R. (2007). Newly homeless youth typically return home. Journal of Adolescent Health, 40(6), 574576. doi:10.1016/j.jadohealth.2006.12.017

Milkie, M. A., Nomaguchi, K. M., \& Denny, K. E. (2015). Does the amount of time mothers spend with children or adolescents matter? Journal of Marriage and Family, 77(2), 355-372. doi:10.1111/jomf.12170

Morewitz, S. J. (2016). Runaway and homeless youth: New research and clinical perspectives. New York: NY: Springer.

Motswi, E. M., \& Mashegoane, S. (2017). The role of sex in the prevalence rates and psychological consequences of cyberbullying among learners in the Limpopo Province, South Africa. Gender and Behaviour, 15(3), 9808-9817. 
Nansel, T. R., Craig, W., Overpeck, M. D., Saluja, G., \& Ruan, W. J. (2004). Cross-national consistency in the relationship between bullying behaviors and psychosocial adjustment. Archives of Pediatrics \& Adolescent Medicine, 158(8), 730-736. doi:10.1001/archpedi.158.8.730

National Conference of State Legislatures (NCSL). (2016). Homeless and Runaway Youth. Retrieved from http://www.ncsl.org/research/human-services/homeless-and-runaway-youth.aspx.

NLS: The National Longitudinal Surveys NLSY97 User's Guide. (2000). Columbus, Ohio: Center for Human Resource Research, The Ohio State University.

O'Donnell, J., Hawkins, J. D., Catalano, R. F., Abbott, R. D., \& Day, L. E. (1995). Preventing school failure, drug use, and delinquency among low-income children: Long-term intervention in elementary schools. American Journal of Orthopsychiatry, 65(1), 87-100. doi:10.1037/h0079598

Olweus, D. (1991). Bully/victim problems among schoolchildren: Basic facts and effects of a school-based intervention program. In D. J. Pepler \& K. H. Rubin (Eds.), The development and treatment of childhood aggression (pp. 411-448). Hillsdale, NJ: Lawrence Erlbaum Associates. doi:10.1007/BF03172807

Parcel, T. L., \& Bixby, M. S. (2016). The ties that bind: Social capital, families, and children's wellbeing. Child Development Perspectives, 10(2), 87-92. doi:10.1111/cdep.12165

Parcel, T. L., \& Dufur, M. J. (2001). Capital at home and at school: Effects on child social adjustment. Journal of Marriage and Family, 63(1), 32-47. doi:10.1111/j.17413737.2001.00032.x

Parcel, T. L., Dufur, M. J., \& Cornell Zito, R. (2010). Capital at home and at school: A review and synthesis. Journal of Marriage and Family, 72(4), 828-846. doi:10.1111/j.17413737.2010.00733.x

Parcel, T. L., \& Taylor, A. J. (2015). The end of consensus: Diversity, neighborhoods, and the politics of public school assignments. Chapel Hill, NC: UNC Press Books.

Polaris. (2019). Polaris: Freedom happens now. Washington, DC. Retrieved from https://polarisproject.org/.

Popp, A. M., \& Peguero, A. A. (2012). Social bonds and the role of school-based victimization. Journal of Interpersonal Violence, 2オ17), 3366-3388. doi:10.1177/0886260512445386

Putnam, R. D. (2000). Bowling alone: The collapse and revival of American community. New York, NY: Simon and Schuster.

Radu, M. B. (2017). Who runs away from home and why? How families, schools, and bullying influence youth runaways. Sociology Compass, 11(11), e12537. doi:10.1111/soc4.12537

Radu, M. B. (2018). Do students' perceptions of unsafe schools and experiences with bullying hinder the effects of family and school social capital in deterring violence? American Behavioral Scientist, 62(11), 1505-1524. doi:10.1177/0002764218787004 
Sampson, R. J., \& Laub, J. H. (1995). Crime in the making: Pathways and turning points through life. Cambridge, MA: Harvard University Press.

Sanchez, R. P., Waller, M. W., \& Greene, J. M. (2006). Who runs? A demographic profile of runaway youth in the United States. Journal of Adolescent Health, 39(5), 778-781.

doi:10.1016/j.jadohealth.2006.04.018

Simons, R. L., \& Whitbeck, L. B. (1991). Sexual abuse as a precursor to prostitution and victimization among adolescent and adult homeless women. Journal of Family Issues, 12(3), 361-379. doi:10.1177/019251391012003007

Shakoor, B. H., \& Chalmers, D. (1991). Co-victimization of African-American children who witness violence: effects on cognitive, emotional, and behavioral development. Journal of the National Medical Association, 83(3), 233.

Substance Abuse and Mental Health Services Administration (SAMHSA). (2004). Substance use among youths who had run away from home. Rockville, MD: The NSDUH Report. Office of Applied Studies.

Tyler, K. A., \& Bersani, B. E. (2008). A longitudinal study of early adolescent precursors to running away. The Journal of Early Adolescence, 28(2), 230-251. doi:10.1177/0272431607313592

Tyler, K. A., Cauce, A. M., \& Whitbeck, L. (2004). Family risk factors and prevalence of dissociative symptoms among homeless and runaway youth. Child Abuse \& Neglect, 28(3), 355-366. doi:10.1016/j.chiabu.2003.11.019

Tyler, K. A., Hagewen, K. J., \& Melander, L. A. (2011). Risk factors for running away among a general population sample of males and females. Youth \& Society, 43(2), 583-608. doi:10.1177/0044118X11400023

Tyler, K. A., Hoyt, D. R., Whitbeck, L. B., \& Cauce, A. M. (2001). The impact of childhood sexual abuse on later sexual victimization among runaway youth. Journal of Research on Adolescence, 11(2), 151-176. doi:10.1111/1532-7795.00008

Tyler, K. A., Schmitz, R. M., \& Ray, C. M. (2018). Role of social environmental protective factors on anxiety and depressive symptoms among Midwestern homeless youth. Journal of Research on Adolescence, 28(1), 199-210. doi:10.1111/jora.12326

Whitbeck, L. B. (2017). Nowhere to grow: Homeless and runaway adolescents and their families. Abingdon, United Kingdom: Routledge.

Whitbeck, L. B., Hoyt, D. R., \& Ackley, K. A. (1997). Abusive family backgrounds and later victimization among runaway and homeless adolescents. Journal of Research on Adolescence, 74), 375-392.

Whitbeck, L. B., Hoyt, D. R., \& Yoder, K. A. (1999). A risk-amplification model of victimization and depressive symptoms among runaway and homeless adolescents. American Journal of Community Psychology, 27(2), 273-296. doi:10.1023/A:1022891802943 
Journal of Youth Development | http://jyd.pitt.edu/ | Vol. 14 Issue 3 DOI 10.5195/jyd.2019.737

Runaway Prevention: Bridging Families and Schools

Whitbeck, L. B., \& Simons, R. L. (1993). A comparison of adaptive strategies and patterns of victimization among homeless adolescents and adults. Violence and Victims, 8(2), 135-152.

Yoder, K. A., Whitbeck, L. B., \& Hoyt, D. R. (2001). Event history analysis of antecedents to running away from home and being on the street. American Behavioral Scientist, 45(1), 51-65. doi:10.1177/00027640121957015

Zych, I., Baldry, A. C., Farrington, D. P., \& Llorent, V. J. (2018). Are children involved in cyberbullying low on empathy? A systematic review and meta-analysis of research on empathy versus different cyberbullying roles. Aggression and Violent Behavior (available online ahead of press). doi:10.1016/j.avb.2018.03.004 